\title{
Developing Love for the Environment-Based Science Comic to Improve Elementary School Student Higher-Order Thinking Skills
}

\author{
Ratih Laila Istiqomah, Postgraduate Student, Faculty of Teacher Training and Education, Universitas \\ Sebelas Maret, Indonesia, ratihistiqomah729@gmail.com, ORCID: 0000-0003-0710-6687 \\ Slamet Subiyantoro, Prof., Faculty of Teacher Training and Education, Universitas Sebelas Maret, Indonesia, \\ s.biyantoro@yahoo.co.id,ORCID: 0000-0002-2236-8194 \\ Peduk Rintayati, Dr., Faculty of Teacher Training and Education, Universitas Sebelas Maret, Indonesia, \\ pedukrintayati@ymail.com, ORCID: 0000-0003-1443-9404
}

\begin{abstract}
Globalization and the 21st century highlight thinking skills and environmental crises as well as careless attitudes towards the culture of the country itself. Meanwhile, one goal of science in elementary education is to make students scientifically curious, improve their scientific attitudes and skills, and turn them into behavior. This study aims to develop a love for the environment-based science comic in elementary schools. This comic uses punakawan shadow puppets as characters. A research and development (R\&D) model was used in this study. The data collection techniques include interview, observation, validator assessment, achievement tests (pretest-posttest), student and teacher responses, and documentation. The results demonstrate that the love for the environment-based science comic can improve student higher-order thinking skills. It is expected that the punakawan shadow puppets used in this study can enrich student citizenship literacy and become a media to maintain the nation's identity.
\end{abstract}

Keywords: Elementary school student, higher order thinking skill, love for the environment, science comic

Received: $14.11 .2020 \quad$ Accepted: 09.12.2020 $\quad$ Published: 17.01.2021

\section{INTRODUCTION}

The development of scientific understanding results in new and creative approaches to solving learning and social problems (Pellegrino, 2018). This makes education in the 21st century emphasize more on increasing the skills needed to learn and maintain learning (Bedir, 2019). Bedir also revealed that teachers should be experts in solving problems professionally, who are very knowledgeable about things such as subject knowledge and pedagogical knowledge. Meanwhile, PISA suggests that some schools respond to the needs of 21st-century learning by reorganizing teachers, rearranging students, rescheduling learning, and changing pedagogical approaches (Schleicher, 2015, p. 10). Thus, education in the 21st century is inseparable from the influence of the development of science and technology. Scientific literacy is the ability to engage with issues related to science and scientific ideas, as reflective citizens (OECD, 2019). Therefore, scientific literacy becomes a very important competency possessed by students.

The process of change in school culture to meet the demands of the 21st century varies from burdening the education system, curriculum and learning design, and teachers with the responsibility of identifying, implementing, achieving, and sustaining 21st-century learning outcomes (Kandari \& Qattan, 2020). The use of the 2013 curriculum in Indonesia is also packaged in such a way that its application can answer the challenges of the 21st century. The Ministry of Education and Culture also stated that curriculum emphasizes on not only higher-order thinking skills (HOTS) but also the spiritual and social attitude competence that can be achieved through indirect learning, i.e. exemplary, habituation, and school culture, taking into account the characteristics of the subjects and the needs and conditions of the students (Ministry of Education and Culture, 2016). The curriculum also encapsulates Indonesia's natural wealth as a theme/topic in learning, including "Ayo Cintai Lingkungan (Let's Love the Environment)" and "Pelestarian Kekayaan Sumber Daya Alam di Indonesia (Preservation of Indonesian Natural Resources" (Ministry of Education and Culture, 2016).

The curriculum design that highlights attitude competence by the Indonesian government is inseparable from the World Resources Institute's report that Indonesia is ranked sixth as the largest carbon-emission country in the world with total carbon emissions of 2.053 billion tons. Meanwhile, the IUCN Red List data states there are 127 plant and 76 animal species in Indonesia that are endangered (Wanabuliandari, 2018). This shows that among all the existing subjects, natural science is a subject that really determines student competence in facing the globalization era. Matsubara argues that, in primary 
science, there are three aspects of evaluation, namely interest, motivation, and attitude towards natural phenomena/events (Matsubara, 2018, p. 61). Thus, science education can be a tool for students to learn about nature and apply it in everyday life (Fakhrudin, Yamtinah, \& Riyadi, 2017).

PISA presents three aspects in the framework of scientific literacy assessment for PISA 2015/2018, namely contents, knowledge, and competencies. In the last aspect, competencies, PISA explains that competencies are the ability to explain phenomena scientifically, evaluate and design scientific investigations, and interpret data and evidence scientifically (OECD, 2019, p. 102). Therefore, scientific attitude guides students in conducting natural science inquiry (Kurniawan, Astalini, Darmaji, \& Melsayanti, 2019). Natural science is a subject that studies forms and events related to the universe to find out about nature systematically (Maison et al., 2020). Thus, science becomes the formation of scientific attitudes through a process of inquiry.

Global climate change is widely regarded as the most disturbing ecological and social crisis faced by humanity in the 21st century. These changes have a profound impact on society, more than any other environmental problem that has ever been witnessed (Anyanwu \& Grange, 2017). As an education activist, we can implement classroom learning oriented to environmental issues. Tugurian and Carrier said that learning is a social practice so it is important to explore the environment and learning modalities that contribute to the development of children's identities as science students and nature explorers (Tugurian \& Carrier, 2016). This is the role of natural science as a scientific attitude. Scientific attitude has a significant influence on the creative personality of students (Park, Kim, \& Jang, 2017). In addition, one attribute of scientific attitude is the responsibility (Chokchai \& Pupat, 2018). Therefore, 21st-century learning focuses on not only academic skills but also life skills that love the environment or are in line with globalization.

The existence of globalization and the demands of education in the 21st century raises the urgency of instilling scientific attitudes in learning. Moreover, Soga \& Gaston (2016) stated that, in the last few decades, the number of people around the world, especially children, who had less interaction with nature, increased, leading to a lot of natural damage due to human ignorance (Soga\& Gaston, 2016). Interestingly, the Blacksmith Institute and the Swiss Green Cross include the Citarum River into the ten poisonous threats in Indonesia (Wanabuliandari, 2018). More broadly, according to the data from NASA, available at Global Forest Watch, Brazil had 39\% more fires between January and August 2019 than in the same period in 2018 (Weisse \& Ruiz, 2019). Besides, the world's attention is on the Arctic's warming twice as fast. Melting permafrost releases methane, a greenhouse gas 28 times stronger than carbon dioxide. Also, researchers have recently discovered that melting permafrost and changes in surface reflectivity in the Arctic will lead to an economic loss of $\$ 67$ trillion (Levin, 2019).

On the other hand, the fact shows that teachers use textbooks more often, and the learning process is still dominated by the lecture method, so the learning atmosphere becomes monotonous and boring; this has an impact on learning achievement about love for the environment, in which, on average, students only get a score below 80. Based on environmental observations and interviews, it shows that the character of love for the environment is also still low. The weak character of the love for the environment leads to the poorly maintained surrounding environment that makes learning activities in class uncomfortable. If within the environment around students are not trained to love the environment, then it is feared the number of 45\%, which, according to the results of Suryadi's study (2015), shows that the millennial have careless behavior, would increase; thus, it is feared that it will have an impact on wider natural damage.

Based on the explanation above, the formation of scientific attitudes, especially love for the environment, is urgent to do. The nature of science learning is teaching students to be involved in investigations (Kurniawan et al., 2019). Kurniawan et al. also revealed that investigations in science can help improve student attitudes and skills. Science shapes student scientific attitudes such as curiosity, critical thinking, open thinking, desire to solve problems, ability to respond to actions, and ability to build a sensitive attitude to the environment (Kurniawan et al., 2019). Therefore, we as education activists make innovation in education through the development of the love for the environment-based science comic for fourth-grade students with the topics "Let's Love the Environment" and "Preservation of Indonesian Natural Resources". Children's environmental identities develop when they experience the world around them and teachers have the potential to use children's connections with nature to foster their interest in science (Tugurian \& Carrier, 2016). This is why we choose elementary school students as research subjects. The development of thinking skills at an early age will determine one's life at a later stage (Sever \& Ersoy, 2019). In addition, achievement in this class has a large influence on children's interests and the development of positive attitudes towards the education and learning environment (Amani, Asadi, \& Nesayan, 2020).

The development of a love for the environment-based science comic is expected to be an effective learning media to improve student higher-order thinking skills to answer the challenges of the 21st century as well as steps in overcoming the ecological crisis due to globalization. Several studies on the use of comics 
have shown improvement of cognitive, motivational, and affective learning outcomes (Istiq'faroh et al., 2020; Lin \& Lin, 2016; Puspitorini et al., 2014). Although there are many studies on the effect of comics on learning, studies on developing comics to improve higher-order thinking skills about love for the environment of elementary school students in natural science subjects are rarely explored. Besides, globalization and the 21st century highlight not only thinking skills and environmental crises but also careless attitudes towards the culture of the country itself. Therefore, we raise Indonesian local wisdom, punakawan shadow puppets, as animated figures in science comics. According to the literature published on the Northern Illinois University website for the South East Asia region (Yusuf \& Darmawan, 2016: 14), punakawan are distinctive characters in Indonesian shadow puppets with a variety of roles, such as an advisor, a knight, an entertainer, a social critic, a clown, and even the source of truth and policy. It is expected that the punakawan shadow puppets used in this study can enrich student citizenship literacy and become a media to maintain the nation's identity. The impact of globalization which undermines cultural boundaries with each other makes the use of punakawan shadow puppets necessary to maintain morality and culture (Murti, Gunarhadi, \& Winarno, 2020).

\section{METHODS}

\section{Research Design}

A research and development (R \& D) model that aims to find, develop, and validate a product is used. The research stages refer to the Borg and Gall's R \& D model (2003), modified by Sukmadinata (2013) into three stages, namely (1) preliminary study/exploration stage, (2) product development stage, and (3) product testing stage.

\section{Participant}

The research subjects were fourth-grade students and teachers of the elementary schools in Karanganyar Regency, Surakarta City, Indonesia. This study involved five public elementary schools which included 121 fourth-grade students and their five class teachers. A simple random sampling technique was used to select the research subjects in the small-scale and large-scale trials while purposive sampling technique was used to select research subjects in the effectiveness test. In addition to involving students and teachers, we also involved four expert validators consisting of a linguist, a media expert, a design expert, and a practitioner.

\section{Data Collection Technique and Instrument}

The data were collected using tests, questionnaires, observations, and documentation. The written test instrument was used to measure students' HOTS about love for the environment as the primary data. The test was validated using Aiken's content validation with an index of $\mathrm{V}=0.75$. The instrument validation yielded 30 valid questions. For the reliability test, the Alpha formula with a significance level of 0.05 was used. The calculation was performed with Iteman application resulting in a score of 0.847 (greater than 0.6 so the question is deemed reliable). The questionnaire was used to collect validation data by experts, student responses, and teacher responses related to the use of the comic, also the primary research data.

\section{Procedure}

The product development stage included (1) expert validation of the prototype (initial concept) of the love for the environment-based science comic, (2) small-scale testing on 8 students in ES 1, where the data obtained through observation and questionnaires were then analyzed, and (3) large-scale testing on 22 students in ES 2 and 28 students in ES 3, where the data obtained through questionnaires and tests were then analyzed. The first product revision was based on the results of expert validation, student and teacher responses, and tests. The product testing was carried out on 36 fourth-grade students in ES 4 as an experimental class and 27 students in ES 5 as a control class. The data obtained through observation and tests were then analyzed.

Data collection techniques in this study included interviews, observation, validator assessment, achievement tests (pretest-posttest), student and teacher responses, and documentation. The data were analyzed using qualitative and quantitative techniques. The qualitative data came from the results of the responses of validators, students, and teachers. The following are the qualitative product evaluation criteria. 
Table 1. Qualitative Data Assessment Criteria

\begin{tabular}{|l|l|l|}
\hline Interval & Criteria & Remark \\
\hline $81 \%-100 \%$ & Very Good & Feasible without revision \\
\hline $61 \%-80 \%$ & Good & Feasible with revision \\
\hline $41 \%-60 \%$ & Enough & Feasible enough with revision \\
\hline $21 \%-40 \%$ & Poor & Less Feasible \\
\hline $0 \%-20 \%$ & Very Poor & Not Feasible \\
\hline
\end{tabular}

Source: Arikunto, Suhardjono \& Supardi (2008).

Meanwhile, the quantitative data were obtained from the pretest and posttest scores of theme 9 on Preservation of Indonesian Natural Resources to refine the next comic draft. To test the data at the product testing stage, a one-group pretest-posttest design was employed (Sugiyono, 2017).

Furthermore, to determine the level of significance of the influence of the science comic before and after learning, student learning outcomes were then tested using the t-test, with the help of SPSS 21.0 for Windows. The product testing stage produced the final draft of the love for the environment-based science comic in the fourth-grade students of elementary schools that had been revised and had the following specifications: first, the front page section including preface, table of contents, instructions for use, characteristics of punakawan, determination of basic competencies and indicators, and summary of love for the environment-based science comics; second, the content page, which discusses the differences between healthy and unhealthy environments, how to protect the environment, the importance of saving energy, the effect of environmental ignorance, looking for issues related to love for the environmental, creating recycled materials, the mandate for love for the environment, and educational games; third, the final section including references, author's identity, and back cover.

\section{RESULTS}

\section{Preliminary Study Stage}

Based on the findings of the preliminary study in the field on thematic learning about love for the environment through media analyses, it was found that teachers used textbooks more frequently and the learning process about love for the environment was also still dominated by the lecture method, which made the learning atmosphere monotonous and boring. This has an impact on the student learning achievement about love for the environment, in which the average score was below 80 . The average scores of the odd semester assessment are shown below.

Table 2. Average Score of Odd Semester Assessment

\begin{tabular}{|l|l|l|}
\hline No. & School & $\begin{array}{l}\text { Average Score of Odd } \\
\text { Semester Assessment }\end{array}$ \\
\hline 1. & ES 1 & 79 \\
\hline 2. & ES 2 & 79 \\
\hline 3. & ES 3 & 72 \\
\hline 4. & ES 4 & 80 \\
\hline 5. & ES 5 & 79 \\
\hline Mean & & $\mathbf{7 8}$ \\
\hline
\end{tabular}

Besides, teachers also had limited learning supporting facilities such as unmaintained school gardens and a lack of book collection in the libraries. The conditions in question, of course, drive teachers and students to support the development of a media in the form of a science comic based on love for the environment. The following is the love for the environment-based science comic developed by the researcher. 

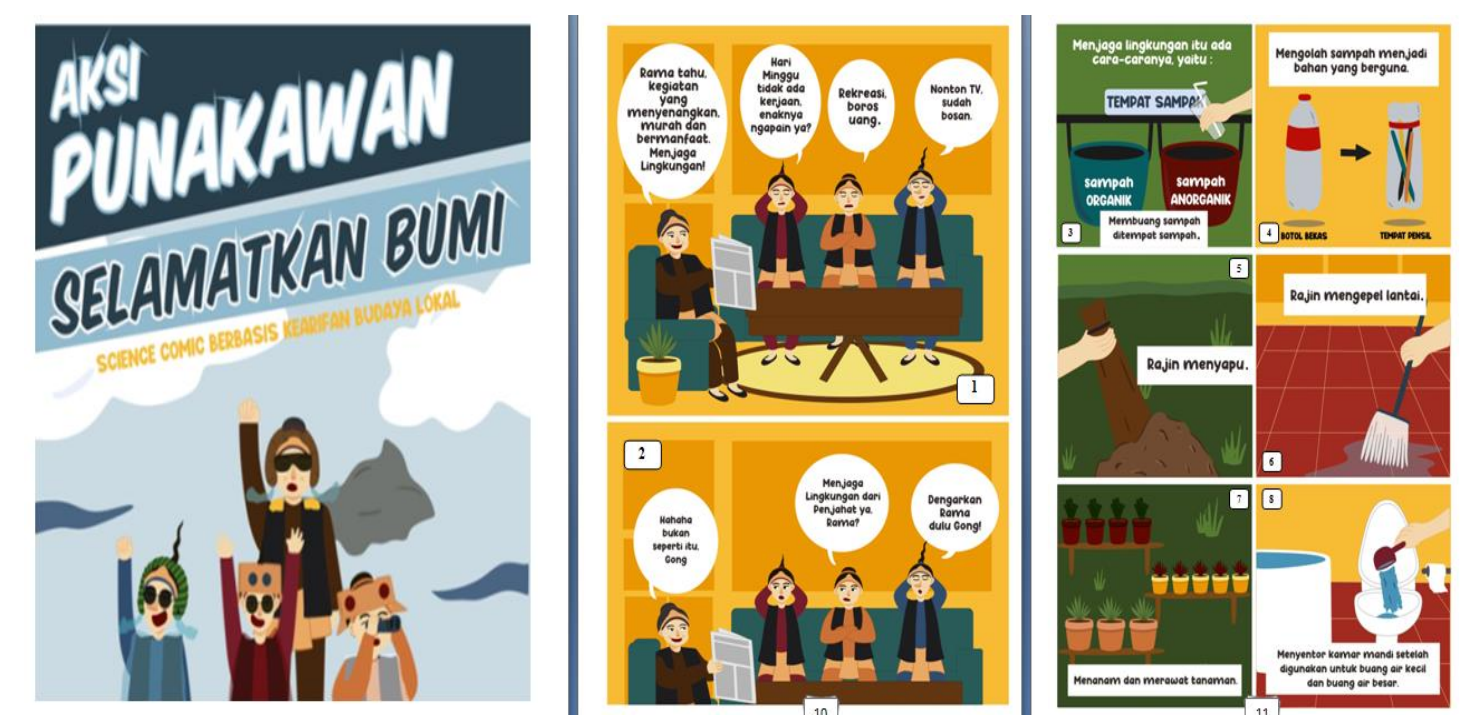

Figure 1. Love for the environment-based science comic, entitled "Aksi Punakawan Selamatkan Bumi (Punakawan's Action to Save the Earth)"

\section{Product Development Stage}

\section{Expert Validation}

There are three assessment aspects of the love for the environment-based science comic, namely language, media, and design. The validators for this assessment consisted of three academics and one practitioner. The aspects assessed by the validators include language, media, and design. Based on the assessment from the three academics and one practitioner, the average score obtained is $80.50 \%$, which is feasible with revision according to Arikunto, Suhardjono \& Supardi's criteria (2008). The validators also provided inputs and suggestions for the improvement of the comic, including (1) the front cover design to be made more attractive, (2) the shape of the image to be made more consistent, (3) the color to be bright, and (4) the writing to be in accordance with the spelling rules and other aspects related to typesetting and font size. Those suggestions and inputs had been improved and revised to draft I.

\section{Small-Scale Trial}

This stage was carried out to find out the weaknesses and shortcomings in the love for the environmentbased science comic as a reference for improvement in the next stage. The following aspects are assessed by the students and teachers.

Table 3. Aspects Assessed by Students and Teachers

\begin{tabular}{|c|c|c|}
\hline Indicator & & Description \\
\hline \multirow{7}{*}{ Appearance } & 1. & The text and writing on this media are easy to read. \\
\hline & 2. & The image presented is not blurred. \\
\hline & 3. & The cover design attracts the readers to read. \\
\hline & 4. & The font type and size chosen are more interesting. \\
\hline & 5. & The color chosen and the combination are suitable and attractive. \\
\hline & & $\begin{array}{l}\text { The animated image and animated characters are in accordance } \\
\text { with the material. }\end{array}$ \\
\hline & 7. & The comic has complete parts. \\
\hline \multirow{5}{*}{$\begin{array}{l}\text { Material } \\
\text { Presentation }\end{array}$} & 8. & The material presented in the science comic is easy to understand. \\
\hline & & $\begin{array}{l}\text { The presentation of the science comic supports the students to } \\
\text { engage in learning. }\end{array}$ \\
\hline & 10. & I can easily understand the sentences used in the comic. \\
\hline & 11. & It has no ambiguous sentence. \\
\hline & 12. & I can understand the terms used in the comic. \\
\hline
\end{tabular}




\begin{tabular}{|l|ll|}
\hline \multirow{4}{*}{ Benefit Aspect } & 13. & $\begin{array}{l}\text { The image of the problems of love for the environment is in } \\
\text { according to the material. }\end{array}$ \\
\hline & 14. & I can understand the material easily. \\
\cline { 2 - 3 } & 15. & $\begin{array}{l}\text { I find it easier to learn about love for the environment using this } \\
\text { comic. }\end{array}$ \\
\cline { 2 - 3 } & 16. & I am very interested in using the science comic. \\
\cline { 2 - 3 } & $\begin{array}{l}\text { I am more excited about learning about love for the environment } \\
\text { using the science comic. }\end{array}$ \\
\cline { 2 - 3 } & $\begin{array}{l}\text { I am more diligent in protecting the environment after learning } \\
\text { with the comic. }\end{array}$ \\
\hline
\end{tabular}

The score obtained from the questionnaires filled out by the students in ES 1 was $80.41 \%$, so it can be concluded from the results of the product assessment by the students that the media developed is in the feasible category with revision. Meanwhile, the score obtained from the product assessment by the teachers at the small-scale trial was $85.55 \%$, so we can say that from the results of the product assessment by the teachers, the media is categorized as very good and feasible to use.

Overall, the responses of the students and teachers to the love for the environment-based science comic developed is good. However, the teachers suggest that the researcher provide symbols or numbers in each conversation to enable the readers to understand the storyline in the science comic. These suggestions and inputs had been corrected and revised to draft II.

\section{Large-Scale Trial}

This large-scale trial was conducted on April 1 to 6, 2019 on 22 students in ES 2 and 28 students in ES 3 so that there were a total of 50 students of the low-, medium-, and high-ability categories in the large-scale trial. This stage aims to find out whether the development of the love for the environment-based science comic has a positive effect on improving the quality of learning so that it can be used on a larger scale. The data on student learning outcomes obtained from the pretest and posttest are presented in Table 5 below.

Table 4. Pretest and Posttest Score Data

\begin{tabular}{|l|l|l|l|l|l|}
\hline Type of Test & $\begin{array}{l}\text { No. of } \\
\text { students }\end{array}$ & Mean & $\begin{array}{l}\text { Standard } \\
\text { Deviation }\end{array}$ & Max & Min \\
\hline Pretest & 50 & 56.84 & 20.64 & 96 & 20 \\
\hline Posttest & 50 & 71.60 & 16.02 & 100 & 32 \\
\hline
\end{tabular}

Based on Table 5, it can be seen the average score of students' achievements about love for the environment has increased by $25 \%$, from 56.84 to 71.60 . It can be concluded that there is an increase in learning achievement from pretest to posttest. Meanwhile, the results of the hypothesis testing on the pretest and posttest data are explained in the following Table 7.

Table 5. Normality, Homogeneity, and t-Test Results

\begin{tabular}{|l|l|l|l|l|}
\hline Testing & Type of Test & Results & Decision & Conclusion \\
\hline Normality & $\begin{array}{l}\text { Kolmogorov- } \\
\text { Smirnov }\end{array}$ & $\begin{array}{l}\text { Sig. Pretest }=0.200 \\
\text { Sig. Posttest }=0.200\end{array}$ & $\begin{array}{l}\mathrm{H}_{0} \text { is } \\
\text { accepted }\end{array}$ & $\begin{array}{l}\text { The data is } \\
\text { normal. }\end{array}$ \\
\hline Homogeneity & Levene's test & Sig. $=0.059$ & $\begin{array}{l}\mathrm{H}_{0} \text { is } \\
\text { accepted }\end{array}$ & $\begin{array}{l}\text { The data is } \\
\text { homogeneous. }\end{array}$ \\
\hline $\begin{array}{l}\text { Pretest-Posttest } \\
\text { Results }\end{array}$ & $\begin{array}{l}\text { Paired Sample t- } \\
\text { Test }\end{array}$ & $\begin{array}{l}\mathrm{t}=-7.806 \\
\mathrm{df}=49 \\
\mathrm{p}=0,000\end{array}$ & $\begin{array}{l}\mathrm{H} 0 \text { is } \\
\text { rejected }\end{array}$ & $\begin{array}{l}\text { The results are } \\
\text { not the same } \\
\text { (there are } \\
\text { differences). }\end{array}$ \\
\hline
\end{tabular}

Based on Table 6, the normality test has a significance level of 0.200 or greater than $\alpha=0.05$ (sig. > 0.05 ). Thus, the pretest and posttest data are normally distributed. Meanwhile, the homogeneity test has a significance level of 0.059 . The significance level obtained indicates that $\mathrm{H}_{0}$ is accepted because the significance level is greater than $\alpha=0.05$ (sig. > 0.05). It can be concluded that the pretest and posttest data came from homogeneous populations or the variance of each sample is the same.

The pretest and posttest data were further analyzed using the paired sample t-test. Based on the table, it is known that $\mathrm{t}=-7.806$ with $\mathrm{df}=49$. The minus ( - ) sign in $\mathrm{t}$ shows the difference in degree between the pretest and posttest scores of 7.806. Based on the table $(0.05: 49)$ is 2.01 , so $t>$ table or the probability 
value is known as $0.000(p<0.05)$, then $\mathrm{H} 0$ is rejected. Thus, pretest and posttest scores have differences or have increased. It can be concluded that the science comic based on local cultural wisdom developed can be used in learning activities.

The feedback given by students to the science comic is the addition of a mandate so that students are increasingly motivated to love the environment. Overall, the students assume that the media is good and can help them learn independently. These suggestions and inputs had been corrected and revised to draft III.

\section{Product Testing Stage}

The product testing stage aimed to find out the effectiveness of the developed media on the achievements of love for the environment in students using the love for the environment-based science comic. The field trial was conducted from April 15 to 26, 2019 on the 36 fourth-grade students in ES 4 as the experimental class and 27 fourth-grade students in ES 5 as the control class.

Before testing the product, both classes must have a balanced initial ability. Therefore, before conducting product testing, the balance test was first carried out using the pretest scores of students from both classes. As a requirement for the balance test to be conducted, the pretest score data must be normally distributed and homogeneous. The data on the results of hypothesis testing on the pretest data are explained in the following Table 6.

Table 6. Normality, Homogeneity, and t-Test Results

\begin{tabular}{|l|l|l|l|l|}
\hline Testing & Type of Test & Results & Decision & Conclusion \\
\hline Normality & $\begin{array}{l}\text { Kolmogorov- } \\
\text { Smirnov }\end{array}$ & $\begin{array}{l}\text { Sig. Experimental }=0.200 \\
\text { Sig. Control }=0.162\end{array}$ & $\mathrm{H}_{0}$ is accepted & The data is normal. \\
\hline Homogeneity & Levene's test & Sig. $=0.904$ & $\mathrm{H}_{0}$ is accepted & $\begin{array}{l}\text { The data is } \\
\text { homogeneous. }\end{array}$ \\
\hline Balance Test & $\begin{array}{l}\text { Independent } \\
\text { Sample t-Test }\end{array}$ & $\begin{array}{l}\mathrm{t}=0.335 \\
\mathrm{df}=61 \\
\mathrm{p}=0,904\end{array}$ & $\begin{array}{l}\mathrm{H}_{0} \text { is accepted } \\
\text { same intents have the } \\
\text { (no difference) }\end{array}$ \\
\hline
\end{tabular}

Based on table 6, the pretest data of the experimental class and the control class are known to have normal and homogeneous distribution. Then, the balance test was carried out through the Independent Sample $t$-Test, which obtained $t=0.335$ with $d f=61$. Based on the $d f$ value, then $t_{\text {table }}(0.05 ; 61)$ was 2.000 . Based on $t$ and $t_{\text {table, }} t<t_{\text {table }}$ or by looking at the probability of $0.904(\mathrm{p}>0.05)$, then $\mathrm{H}_{0}$ is accepted. This shows that both classes have the same initial abilities so that they can be used for the product testing stage.

Furthermore, the researcher conducted product testing in the experimental class using the love for the environment-based science comic developed and using the conventional method in the learning control class. The following are the results of students' pretest and posttest in the experimental class and the control class.

Table 7. Test Result Data of Experimental Class

\begin{tabular}{|l|l|l|l|l|l|}
\hline $\begin{array}{l}\text { Type of } \\
\text { Test }\end{array}$ & $\begin{array}{l}\text { No. of } \\
\text { students }\end{array}$ & Mean & Min. Score & Max. Score & $\begin{array}{l}\text { Average } \\
\text { Increase }\end{array}$ \\
\hline Pretest & 36 & 68.94 & 36 & 96 & $26.74 \%$ \\
\hline Posttest & 36 & 87.38 & 64 & 100 & 26.0 \\
\hline
\end{tabular}

Table 8. Test Result Data of Control Class

\begin{tabular}{|l|l|l|l|l|l|}
\hline $\begin{array}{l}\text { Type of } \\
\text { Test }\end{array}$ & $\begin{array}{l}\text { No. of } \\
\text { students }\end{array}$ & Mean & Score & Max. Score & $\begin{array}{l}\text { Average } \\
\text { Increase }\end{array}$ \\
\hline Pretest & 27 & 67.70 & 32 & 96 & \multirow{2}{*}{$13.35 \%$} \\
\hline Posttest & 27 & 76.74 & 44 & 96 & \\
\hline
\end{tabular}

Table 7 and Table 8 show that there is a significant difference between the test results in the experimental class and the control class; the average score of the experimental class increased by $26.74 \%$, while that of the control class only increased by $13.35 \%$.

The last stage of product testing is the effectiveness test using the difference between the pretest and posttest scores in the experimental and control classes, often known as the gain-score results. In the following Table 9, you can see the gain-score results in the experimental class and the control class. 
Table 9. Gain Scores of Experimental and Control Classes

\begin{tabular}{|l|l|l|l|l|}
\hline Student Group & \multirow{2}{*}{ Frequency } & \multicolumn{2}{|l|}{ Mean Score } & \multirow{2}{*}{ Mean } \\
\cline { 3 - 4 } & & Min & Max & \\
\hline Experimental & 36 & 4 & 32 & 18.44 \\
\hline Control & 27 & 0 & 24 & 9.03 \\
\hline
\end{tabular}

The gain-score data in the experimental class and the control class were then analyzed using the normality, homogeneity, and post hoc tests. The data on the results of normality and homogeneity gain scores of the experimental and control classes are explained in the following Table 10.

Table 10. Normality and Homogeneity Gain Scores

\begin{tabular}{|l|l|l|l|l|}
\hline Testing & Type of Test & Results & Decision & Conclusion \\
\hline Normality & $\begin{array}{l}\text { Kolmogorov- } \\
\text { Smirnov }\end{array}$ & $\begin{array}{l}\text { Sig. Experimental }=0.062 \\
\text { Sig. Control }=0.113\end{array}$ & $\mathrm{H}_{0}$ is accepted & $\begin{array}{l}\text { The data is } \\
\text { normal. }\end{array}$ \\
\hline Homogeneity & Levene's test & Sig. $=0.551$ & $\mathrm{H}_{0}$ is accepted & $\begin{array}{l}\text { The data is } \\
\text { homogeneous. }\end{array}$ \\
\hline
\end{tabular}

The next step after knowing that the gain-score data in the experimental class and the control class are normally distributed and homogeneous is to do the posthoc test through the Independent Sample tTest. This test aimed to prove whether there were mean differences between two independent samples, where both had been given different treatments i.e. the experimental class with the developed media and the control class with the conventional method. The analysis of the Independent Sample t-Test results is shown in Table 11 below.

Table 11. Independent Sample t-Test Results

\begin{tabular}{|l|l|l|l|l|}
\hline Testing & Type of Test & Results & Decision & Conclusion \\
\hline $\begin{array}{l}\text { Gain Score of } \\
\text { experimental } \\
\text { and control } \\
\text { classes }\end{array}$ & Independent & $\mathrm{t}=4.982$ & $\begin{array}{l}\mathrm{H}_{0} \text { is } \\
\text { Sejected } \\
\mathrm{df}=61 \\
\mathrm{p}=0,000\end{array}$ & $\begin{array}{l}\text { There are differences in } \\
\text { the achievements of } \\
\text { students who use the love } \\
\text { for the environment-based } \\
\text { science comic. }\end{array}$ \\
\hline
\end{tabular}

Based on Table 11, it is known that $\mathrm{t}=4.982$ with $\mathrm{df}=61$, showing the difference in the degree of difference between the gain scores of the experimental class and the control class is 4.982 , while the table $(0.05 ; 61)$ is 2.000 . Thus, based on $t>t_{\text {table }}$ or by looking at the probability of $0.000(\mathrm{p}<0.05)$, then $\mathrm{H}_{0}$ is rejected. This indicates that there are differences in the achievements of students in the experimental class using the love for the environment-based science comic and in the control class using only the conventional method; the experimental class obtained higher test results than did the control class.

\section{DISCUSSION AND CONCLUSIONS}

Based on the research and development carried out, the love for the environment-based science comic media can improve elementary school students' HOTS. This can be seen from the results of the product assessment by the validators, in which the developed science comic scored $80.50 \%$, the students scored $80.41 \%$, and the teachers scored $85.55 \%$. This is influenced by the use of the punakawan shadow puppets as animated characters who teach the love for the environment to students. This is as stated by Zamzami \& Subiyantoro (2014) that punakawan shadow puppets have noble behaviors and traits that students can take examples from and foster their knowledge and revive the native culture of Indonesia to be better known early on. Punakawan are a manifestation of several forms and traits of human characters that have many philosophical values and can set an example for human life (Hidayah \& Waluyo, 2019). Capellita \& Lestari (2019) also believe that punakawan have an intelligent side, both in speaking, creating an extraordinary atmosphere, being innocent, and, most importantly, influencing others.

Besides, according to tables 4 and 5, the comic has an impact on increasing student learning outcomes, which proves that media, as one of the elements of learning, is very necessary to generate motivation to learn and present the basic concepts that are correct, concrete, and realistic (Riyana, 2008). The use of educational media in teaching is also needed to encourage students to develop $21^{\text {st-century skills }}$ (i.e. critical thinking, creativity, communication, and collaboration) to help them master the content and solve problems (Boyle et al., 2014; Qian \& Clark, 2016). The teacher belief is also involved in equipping 


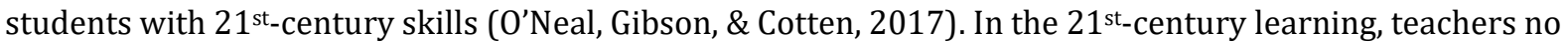
longer transmit knowledge but must be able to use inquiry strategies so students can gain good grades, knowledge, and scientific skills (Saputro, Irwanto, Atun, \& Wilujeng, 2019). The packaging of stories in comics with punakawan shadow puppets as the characters makes students no longer feel burdened by natural science subject matter. They also learn about the character of love for the environment through the puppet character, which can improve their HOTS.

HOTS consists of three areas namely (1) scientific inquiry, (2) creative problem discovery and problem solving, and (3) future thinking - personal perspective and time (Vidergor, 2017). In 21st-century learning, students are required to not only understand various concepts but also analyze environmental problems around them related to global warming (Ichsan et al., 2019). The design of the comic can motivate the students to investigate the importance of love for the environment. As found by Ryu et al., the students admitted that the use of Japanese anime was very enjoyable and provided a good example for practicing making logical assumptions around real-world applications (Ryu, Zhang, Peteranetz, \& Daher, 2020). Like this study, student curiosity increases because of the use of the comic with punakawan characters. Apart from the fact that the media used previously was only the textbook from the government, the science comic gives rise to the curiosity of students who have not known Indonesian puppetry. In fact, punakawan is the wisdom of the Indonesian people. This can foster an attitude of respecting the cultural values of Indonesian

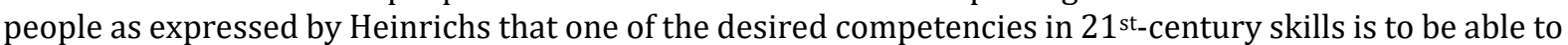
find values in the various cultures that enter (Heinrichs, 2016). The science material in this comic is also fun for students because the packaging of the story is different from before. This is following Dales's cone of Experience, in which the use of media that contains images and videos can help students to understand and remember by $30 \%$ (Davis \& Summers, 2015).

Although the results of the product assessment had been in a good category, the validators also provided suggestions for improvement, so that the love for the environment-based science comic can be more perfect. Improvements to the love for the environment-based science comic include (1) the front cover design to made more attractive, (2) the shape of the image to be made more consistent, (3) the color used to be bright, (4) the writing to be in accordance with the spelling rules, and (5) the symbol or number to be written on each conversation, as well as several other aspects related to typesetting and font size. The suggestions and inputs had been improved and revised to draft III before being tested on a larger scale at the product testing stage.

At the product testing stage, the researcher used one experimental class and one control class. Before giving the comic for learning, the researcher conducted a pretest to determine the initial ability of the students. After that, the experimental class was taught using the comic while the control class was only taught using the textbook from the government. After the two classes had been given different treatments, posttests were administered to find out the effectiveness of the use of the comic in thematic learning. In addition to providing pretest and posttest, the students also filled out the questionnaires to find out their responses to the learning conducted. The results of the pretest and posttest in table 7 and table 8 show that there are differences in student achievement in the experimental class, which is higher than the control class only using textbooks. That is because comics have a visual appeal, efficiency, and message strength (Fay, 2009) that can increase interest and understanding of science (Chung, Park, Kim, Cho, \& Chung, 2016). Besides, science comic is considered by some science educators as an important means to explore scientific information in ways that are interesting, accurate, and easy to understand (Dallacqua \& Peralta, 2019; Roesky \& Kennepohl, 2008; Tatalovic, 2009; Weitkamp \& Burnet, 2007) Therefore, it is an interesting and potential media to communicate science and knowledge to students (Collver \& Weitkamp, 2018).

The students respond well to the science comic developed. They find it easier to understand material about love for the environment. Science comic is a form of cartoons that portrays a story containing the concepts of science, thus creating learning that is more relevant, easy to learn and remember, and better describes the real situation (Arroio, 2011). The students also admit that they become more aware to love the environment after learning with the love for the environment-based science comic, especially in terms of maintaining environmental cleanliness and energy savings. This response is in accordance with the opinions of Juanda et al. (2015) suggesting that with the strengthening of concepts in students, science comic can stimulate and shape their characters and teach them good habits. Comic media simplifies the concept of science (Özdemir, 2017) so that it can successfully affect student awareness of natural environmental issues (Hands, Shaw, Gibson, \& Miller, 2018).

The development of this comic can increase HOTS in elementary school students. $21^{\text {st }}$-century learning emphasizes not only the academic aspects but also aspects of life skills and career. Increasing student awareness about love for the environment is proof that one of the goals of science in elementary education is to make students scientifically curious, improve their scientific attitudes and skills, and turn them into behavior (Yllmaz, 2007). The results of this study show the achievement of science learning goals 


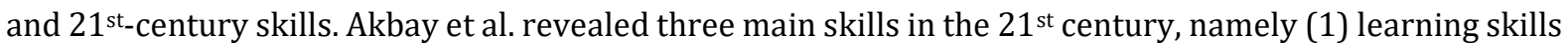
and innovation, (2) information, media, and technology skills, and (3) life skills and career. These skills must be mastered by students to address the main problems of the $21^{\text {st }}$ century including environmental literacy and citizenship literacy. Therefore, globalization and the $21^{\text {st }}$ century highlight not only thinking skills and environmental crises but also careless attitudes towards the culture of the country itself. This is because the impact of globalization which undermines cultural boundaries with each other makes the use of punakawan shadow puppets necessary to maintain morality and culture (Murti, Gunarhadi, \& Winarno, 2020). The punakawan shadow puppets in this study can enrich student citizenship literacy and become a media to maintain the nation's identity.

This study concludes that, first, the love for the environment-based science comic is effective for thematic learning, especially on the topics "Let's Love the Environment" and "Preservation of Indonesian Natural Resources". It is shown by the average score of the expert assessment in the preliminary study of $80.50 \%$ while the average score of the students' responses to the development of the science comic is $80.41 \%$. Based on the $\mathrm{t}$-test, the student achievement at the product development stage before and after the use of love for the environment-based science comic increases by 7.806. At last, the student learning achievement in the experimental class at the product testing stage is higher than that in the control class with a t-test score of 4.982 . Second, with this science comic, students can understand the material about love for the environment more easily so that it helps students to learn independently. Third, this science comic can increase student motivation to care about the environment. Finally, it helps teachers to improve the quality of learning about love for the environment while developing teaching references on themes or other materials.

Despite the effectiveness of this study in improving learning, there are some limitations encountered. First, the making of the science comic must involve a graphic design expert, so it takes a long time and high cost. Second, this study involves a limited sample; future researchers are suggested to recruit broader samples to obtain comprehensive findings. In addition, in this study, the teacher does not invite his students to see the natural conditions around them directly or analyze problems through audiovisual media. Therefore, it would be better if comic science is combined with outdoor learning or experiential learning so that students will experience directly in solving problems in the natural environment.

\section{REFERENCES}

Akbay, T., Sivacı, S. Y., \& Akbay, L. (2020). Investigation of Teacher Candidates' 21st Century Learner Skills via PAMS. Elementary Education Online, 19(3), 1498-1508. https://doi.org/10.17051/ilkonline.2020.731177

Amani, M., Asadi, R., \& Nesayan, A. (2020). A Study of Academic Factors Underlying First Grade Retention in Primary Schools of North Khorasan. International Electronic Journal of Elementary Education, 12(4), 325-333. https://doi.org/10.26822/iejee.2020459462

Anyanwu, R., \& Grange, L. Le. (2017). The Influence of Teacher Variables on Climate Change Science Literacy of Geography Teachers in the Western Cape, South Africa. International Research in Geographical and Environmental Education, 26(3), 193-206. https://doi.org/10.1080/10382046.2017.1330039

Arikunto, S., Suhardjono \& Supardi. (2008). Penelitian Tindakan Kelas [Classroom Action Research]. Jakarta: PT Bumi Aksara.

Arroio, A. (2011). Comics as A Narrative in Natural Science Education. Western Anatolia Journal of Educational Science, ISSN 1308-8971, 93-98. Retrieved from http://webb.deu.edu.tr/baed/giris/baed/ozel_sayi/93-98.pdf.

Bedir, H. (2019). Pre-service ELT teachers' Beliefs and Perceptions on 21st Century Learning and Innovation Skills (4Cs). Journal of Language and Linguistic Studies, 15(1), 231-246. https://doi.org/10.17263/jlls.547718

Boyle, E. A., Macarthur, E. W., Connolly, T.M., Hainey, T., Manea, M., Kärki, A., \&Van Rosmalen, P. (2014). A narrative literature review of games, animations and simulations to teach research methods and statistics. Computers and Education, 74, 1-14. https://doi.org/10.1016/j.compedu.2014.01.004

Capellita, M.B., \& Lestari, N. S. (2019). Digital Life Society Education from Punakawan History. Journal of Physics: Conference Series, 1339 (2019) 012086, doi:10.1088/1742-6596/1339/1/012086.

Chokchai, O., \& Pupat, P. (2018). A Student's Scientific Mind: A Confirmatory Factor Analysis. Malaysian Journal of Learning and Instruction, 15(2), 1-31.

Chung, B. S., Park, E., Kim, S., Cho, S., \& Chung, M. S. (2016). Comic Strips to Accompany Science Museum Exhibits. Journal of Education and Learning, 5(4), 141-146. https://doi.org/10.5539/jel.v5n4p141

Dallacqua, A. K., \& Peralta, L. R. (2019). Reading and (Re) writing Science Comics : A Study of Informational Texts. The Reading Teacher, 73(1), 111-118. https://doi.org/10.1002/trtr.1801 
Fakhrudin, A., Yamtinah, S., \& Riyadi. (2017). International Online Journal of Primary Education. International Online Journal of Primary Education, 6(2), 30-38.

Fay, D. (2009). Student storytelling through sequential art. English Teaching Forum Journal, 45(3). Retrieved from https://eric.ed.gov/?id=EJ1099406.

Heinrichs, C. R. (2016). Exploring the Influence of 21st Century Skills in a Dual Language Program: A Case Study. International Journal of Teacher Leadership, 7(1), 37-56.

Hidayah, N., \& Waluyo, E. (2019). The Use of Punakawan “Novel Graphic” for Increasing Early Childhood's Knowledge about Cultural Heritage, Early Childhood Education Papers, 8(1), 43-47. DOI: http://dx.doi.org/10.15294/belia.v8i1.30655.

Ichsan, I. Z., Sigit, D. V., Miarsyah, M., Ali, A., Arif, W. P., \& Prayitno, T. A. (2019). HOTS-AEP: Higher Order Thinking Skills from Elementary to Master Students in Environmental Learning. European Journal of Educational Research, 8(4), 935-942. https://doi.org/10.12973/eu-jer.8.4.935

Istiq'faroh, N., Suhardi, S., \& Mustadi, A. (2020). Improving Elementary School Students' Creativity and Writing Skills Through Digital Comics. Elementary Education Online, 19(2), 426-435

Kandari, A. M. Al, \& Qattan, M. M. Al. (2020). E-Task-Based Learning Approach to Enhancing 21st-Century Learning Outcomes. International Journal of Instruction, 13(1), 551-566.

Kurniawan, D. A., Astalini, A., Darmaji, D., \& Melsayanti, R. (2019). Students' Attitude towards Natural Sciences. International Journal of Evaluation and Research in Education, 8(3), 455-460. https://doi.org/10.11591/ijere.v8i3.16395

Levin, K. (2019). From Climate Researcher to Climate Spectator: Witnessing a Melting Arctic. Diperoleh pada 4 September 2019. Retrieved from https://www.wri.org

Lin, S.F., \& Lin, H. (2016). Learning Nanotechnology with Texts and Comics: The Impacts on Students of Different Achievement Levels. International Journal of Science Education, 38(8), 1373-1391. doi:10.1080/09500693.2016.1191089

Maison, M., Haryanto, H., Ernawati, M. D. W., Ningsih, Y., Jannah, N., Puspitasari, T. O., \& Putra, D. S. (2020). Comparison of Student Attitudes towards Natural Sciences. International Journal of Evaluation and Research in Education, 9(1), 54-61. https://doi.org/10.11591/ijere.v9i1.20394

Matsubara, K. (2018). Elementary Science Education in Japan. In T. J. Lee YJ. (Ed.), Primary Science Education in East Asia. Contemporary Trends and Issues in Science Education, vol 47 (pp. 49-77). Cham: Springer.

Ministry of Education and Culture. (2016). Silabus Sekolah Dasar/Madrasah Ibtidaiyah [Syllabus of Public and Islamic Elementary Schools]. Jakarta.

Murti, D. K., Gunarhadi, \& Winarno. (2020). Development of Educational Comic with Local Wisdom to Foster Morality of Elementary School Students: A Need Analysis. International Journal of Educational Methodology, 6(2), 337-343. https://doi.org/10.12973/ijem.6.2.337

O’Neal, L. J., Gibson, P., \& Cotten, S. R. (2017). Elementary School Teachers' Beliefs about the Role of Technology in 21st-Century Teaching and Learning. Computers in the Schools, 1-15. https://doi.org/10.1080/07380569.2017.1347443

OECD. (2019). PISA 2018 Assessment and Analytical Framework. Paris: OECD Publishing. https://doi.org/https://doi.org/10.1787/b25efab8-en.

Özdemir, E. (2017). Humor in Elementary Science: Development and Evaluation of Comic Strips about Sound. International Electronic Journal of Elementary Education, 9(4), 837-850.

Özdemir, E., \& Eryılmaz, A. (2019). Comics in Science Teaching: A Case of Speech Balloon Completing Activity for Heat Related Concepts. Journal of Inquiry Based Activities, 9(1), 37-51.

Park, J., Kim, M., \& Jang, S. (2017). Analysis of Factors Influencing Creative Personality of Elementary School Students. International Education Studies, 10(5), 167-180. https://doi.org/10.5539/ies.v10n5p167

Pellegrino, J. W. (2018). Sciences of Learning and Development: Some Thoughts from The Learning Sciences. Applied Developmental Science, 1-9. https://doi.org/10.1080/10888691.2017.1421427

Puspitorini, Prodjosantoso, Subali \& Jumadi. (2014). Penggunaan Media Komik dalam Pembelajaran IPA untuk Meningkatkan Motivasi dan Hasil Belajar Kognitif dan Afektif [The Use of Comic Media in Science Learning to Enhance Cognitive and Affective Learning Motivation and Outcomes]. Cakrawala Pendidikan Universitas Negeri Yogyakarta, 3, 413-420. Retrieved from https://www.researchgate.net.

Qian, M., \& Clark. K., R. (2016). Game-based learning and 21st century skills: A review of recent research. Computers in Human Behavior, 63, 50-58. https://doi.org/10.1016/j.chb.2016.05.023.

Riyana, C. (2008). Konsep dan Aplikasi Media Pembelajaraan [Concept and Application of Learning Media]. Retrieved from http://file.upi.edu/Direktori//../08_Media_Pembelajaran_pdf.

Roesky, H. W., \& Kennepohl, D. (2008). Drawing Attention with Chemistry Cartoons. Journal of Chemical 
Education, 85(10), 1355-1360, https://doi.org/10.1021/ed085p1355.

Ryu, S., Zhang, H., Peteranetz, M., \& Daher, T. (2020). Fluid Mechanics Education Using Japanese Anime: Examples from "Castle in the Sky" by Hayao Miyazaki. The Physics Teacher, 58(4), 230-233. https://doi.org/10.1119/1.5145464

Saputro, A. D., Irwanto, Atun, S., \& Wilujeng, I. (2019). The Impact of Problem Solving Instruction on Academic Achievement and Science Process Skills among Prospective Elementary Teachers. Elementary Education Online, 18(2), 496-507. https://doi.org/10.17051/ilkonline.2019.561896

Schleicher, A. (2015). Schools for 21st-Century Learners Innovative Approaches. International Summit on the Teaching Profession, OECD Publishing.

Sever, I., \& Ersoy, A. (2019). Investigation of Decision-Making Skills of Fourth Grade Students According to Student and Teacher Opinions. International Electronic Journal of Elementary Education, 12(2), 167-182. https://doi.org/10.26822/iejee.2019257664

Soga, M., \& Gaston, K., J. (2016). Extinction of Experience: The Loss of Human-Nature Interactions. The Ecological Society of America Journal, 14(2), 94-10, https://doi.org/10.1002/fee.1225

Sugiyono. (2017). Metode Penelitian Pendidikan: Pendekatan Kuantitatif, Kualitatif, dan R \& D [Educational Research Method: Quantitative, Qualitative, and R \& D Approaches]. Bandung: Alfabeta.

Sukmadinata. (2013). Metode Penelitian Pendidikan [Educational Research Method]. Bandung: PT Remaja Rosdakarya.

Suryadi, B. (2015). Generasi Y: Karakteristik, Masalah, dan Peran Konselor [Generation Y: Characteristics, Problems and Role of Counselors]. Seminar dan Workshop Internasional MALINDO, 1-8. Retrieved from http://repository.uinjkt.ac.id/dspace/handle/123456789/34351

Tatalovic, M. 2009. Science comic as Tools for Science Education and Communication: a Brief, Exploratory Study. Journal of Science Communication, 8(4), 1-16. https://doi.org/10.22323/2.08040202.

Tugurian, L. P., \& Carrier, S. J. (2016). Children's Environmental Identity and the Elementary Science Classroom. The Journal of Environmental Education, 1-11. https://doi.org/10.1080/00958964.2016.1191415

Vidergor, H. E. (2017). Effectiveness of The Multidimensional Curriculum Model in Developing Higherorder Thinking Skills in Elementary and Secondary Students. The Curriculum Journal. https://doi.org/10.1080/09585176.2017.1318771

Wanabuliandari, et al. (2018). E-Jas Module: Effort to Improvement The Environmental Care and Responsibility Character. Atlantis Press: Advances in Social Science, Education and Humanities Research, 203, 181-123. https://doi.org/10.2991/iclick-18.2019.25

Weisse, M., \& Ruiz, S. (2019). What Can Global Forest Watch Tell Us About the Fires in Brazil?. Retrieved from https://www.wri.org.

Weitkamp, E., \& Burnet, F. (2007). The Chemedian Brings Laughter to The Chemistry Classroom. International Journal of Science Education, 29(15), 1911-1929. https://doi.org/10.1080/09500690701222790.

Yllmaz, F. (2007). Teachers' Opinions about the Effectiveness of Science Course to Have Students Acquire Scientific Attitude and Behavior in Elementary School. Elementary Education Online, 6(1), 113-126.

Yusuf, R \& Darmawan, W. (2016). Aplikasi Berbasis Web dengan Menggunakan Pustaka Javascript Fabricjs untuk Pembuatan Komik Strip Punakawan [Web-Based Application Using Fabricjs Javascript Library for Making Punakawan Strip Comics]. National Seminar on Information Technology and Multimedia of STMIK Amikom Yogyakarta, 13-18. Retrieved from ojs.amikom.ac.id.

Zamzami, M.F., \& Subiyantoro, H. (2014). Komik Edukasi Pewayangan Punakawan sebagai Keteladanan bagi Remaja Usia 13-15 Tahun [Punakawan Shadow Puppet Education Comic as Exemplary for Teenagers Aged 13-15 Years]. Creativitas , 3(2), 367-380. 